\title{
RESEÑA: GEORGE MOORE: ARTISTIC VISIONS AND LITERARY WORLDS. MARY PIERSE (ED) ${ }^{1}$
}

\author{
David Clark ${ }^{2}$
}

\author{
Mary Pierse (ed.). 2006. George Moore: Artistic Visions and Literary Worlds. New- \\ castle: Cambridge Scholars Press. 246 págs. ISBN 1-84718-029-9.
}

Yeats once stated, paraphrasing the French diplomat Talleyrand, that George Moore possessed "the terrible gift of familiarity" (qtd. Foster 1997: 200). Taken, admittedly out of context, and over a century later, the great poet's words must surely invoke a certain sensation of irony in anyone familiar with the literary heritage of George Moore (1852-1933). Moore, of course, was the Renaissance man of Irish letters - an accomplished novelist, poet, dramatist, writer of short stories, pictorial artist and critic of art- at a time when Irish letters (Moore was contemporary and friend of both Yeats and Joyce) stood tall and proud on the world literary stage. The "familiarity"-indeed the great literary industries which have sprung up around Yeats and Joyce- have somehow been lost in the case of Moore. The literary reputation of this great, multifaceted writer who, at one time was ranked alongside Zola and seen as the great master of English-language naturalism; who was one of the cornerstones of the Irish Literary Revival, has dwindled since his death and as such "Moore was often treated as an influence, a predecessor, or a character in the story of another, not as a central figure in his own right, whose best works could never grow old" (Frazier 2000: xi).

The present volume, skilfully edited by Moore Scholar Dr Mary Pierse, seeks in many ways to redress the balance; to pay, as it were, historical justice to Moore's outstanding legacy. If Adrian Frazier in 2000 began a new era in Moore scholarship with his masterly critical autobiography from which I have quoted above, Pierse presents a lucid and comprehensive volume in which scholars from Ireland, France, the USA, Spain, the UK, Japan and Brazil examine various facets of the writer's works.

George Moore: Artistic Visions and Literary Worlds spurns any simplistic division of Moore's writings and, as such, omits potentially straight-jacketing genre divisions in its structure. The volume is thus divided into five sections in which, in the words of Pierse herself "relate to their common interests, but between the sections, essays also interconnect" (xii). Such an arrangement provides the additional advantage of providing a work which is internally coherent and immensely readable in itself, not simply as a collection of essays, but rather as an inherently articulate book in its own right.

The first section, subtitled "Portraits of the Artist", contains three essays which attempt to give different "portraits" of Moore, broadly dealing with the dichotomy between life

Date of reception: September 2007.

Date of acceptance and final version: September 2007.

2 Senior Lecturer, Departamento de Filoloxía Inglesa, Universidade da Coruña; $₫$ dclark@udc.es. 
and art in the author's life and in his works. Adrien Frazier, author of the groundbreaking autobiography referred to above, studies the downturn in the literary reputation of Moore and the "irreparable damage" caused to this by Yeats" Autobiographies, concluding that Moore, along with Joyce, was one of the few "serious writers to treat the English novel as an art form" (9). Fabienne Gaspari analyses the concept of artistic failure and the hardships of artistic production in relation to Moore's oeuvre. Her studies of Moore's "portraits of artists" within his work remark upon the difficulty of encountering "real" boundaries between fiction and life, and the importance this has in pivotal works such as his second novel, A Mummer's Wife (1885) discovering, in Moore's works "an unmistakeable metafictional component that foreshadows modernism" (22). Ann Heilman concludes the section with an interesting essay which studies the relationship between hysteria and the artist, with special reference to the tragedy of the failed artist and the subsequent threats of hysteria, depression and suicide.

The second section, "Wider Horizons", offers a series of essays which examine Moore's constant attempts to break the shackles of conformity and to explore new artistic courses. Fabienne Garcier studies Moore's contribution to the Irish short story and his respect for and skill with the genre. Siofra Pierse provides a thought-provoking comparison between Moore and Voltaire and touches on the influence of the rationalist thought of the Enlightenment on the author and the role this played in his dissatisfaction with the Irish Renaissance. Albert Lázaro Lafuente, a renowned specialist on the application of the censorship laws of the Franco regime on English-language writers, provides an overwhelming amount of evidence regarding the censorship of Moore's work from the Spanish National Library Archives. Munira Mutran concentrates on Moore's autobiographical output and uses a Latin American prism through which to view Moore's Confessions of a Young Man (1888) and Hail and Farewell (1911-14).

"Smooth Passages", the third section of the book, centres on Moore's apparently effortless treatment of the subjects of sex, religion and politics in his works. Konstantin Doulamis' painstaking and thorough study of Moore's 1924 novel The Pastoral Loves of Daphnis and Chloe claims that Moore's adaptation of Longus' text "almost rivals the original, which is itself a text of considerable sophistication" (99). Mary Pierse examines the political and religious background of the writer and the presence of this influence in his work, in which, she claims, the democratic liberalism and love of freedom inherited from his father is continually apparent.

Part IV, "Close Encounters", includes a series of essays which broadly examine the stylistic concerns of the author. Pádraigin Riggs presents a close reading of Moore's 1902 collection of short stories in Irish, An t-Úr-Ghort, in which the Irish scholars Tadgh Ó Donnchadha and Pádraig Ó Súilleabháin had actively participated, and Moore's own 1903 collection The Untilled Field, concluding that it is highly likely that these works influenced that of Pádraic Ó Conaire, the most brilliant and successful Irish-language writer of the Irish Language Revival. This influence, Riggs argues, is of course highly compatible with Moore's declared intent at the time of providing any help and encouragement possible to revive the use and divulgation of the Irish language. Brendan Fleming reveals the existence of a hitherto forgotten version of Moore's 1895 novella "Mildred Lawrence" which had appeared in the magazine Lady's Pictorial in February and March of 1888. Fleming's study 
re-dates Moore's use of the internal monologue using the evidence found in the serial, and thus sees the Irish writer's separation from Zola's style as being earlier than the date that had been earlier supposed. Christine Huguet provides a highly detailed study of Moore's most famous work, Esther Waters, delving through the numerous versions both in prose and in play format, showing how Moore's changes in his work reveal his immense dedication and perfectionism. In a highly readable chapter, Lucy McDiarmid investigates the "intractability" of the Irish material in Moore's Hail and Farewell.

The fifth and final section, "The Gender Question Marks", presents a series of essays which examine various facets of the question of gender in Moore's works. María Elena Jaime de Pablos studies Moore's heroines from 1886 to 1922, suggesting that Moore "chose to serve the feminist cause (...) by integrating their experiences into literary discourse" (193) and that Moore's works ultimately contain a high degree of social criticism which comes into conflict with a social reality which is strongly patriarchal and male-centred. Catherine Smith examines the use of animal tropes for women in his 1887 novel A Drama in Muslin. Such imagery, for Smith, supplies the writer with "an effective artistic method of depicting the social savagery of the novel's milieu" (204). Both Michael O'Sullivan and Mark Llewellyn deal with the question of celibacy in Moore's writings. While both writers recognise the importance of celibacy in his work, overtly present, in fact, in two titles, Celibates and Celibate Lives, and the sexual condition of many important characters, not least Mildred Lawson and John Nobbs, O'Sullivan shows how the concept of narrative as metaphor for seduction becomes "unstuck" when celibacy is central to the narrative while Llewellyn stresses the point to which Moore "seeks to reassert the individual's right to be celibate through choice, rather than through compulsion or duty" (230).

George Moore: Artistic Visions and Literary Worlds, is an important volume which should be obligatory reading for anyone interested not only in Irish writing, but also for those with an interest in the quirky period in which naturalism moved towards modernism, in which art strives to push its boundaries further than ever before. Moore was, perhaps, too much of an all-round intellectual to fit in to any neat pigeonhole, and Pierse's volume provides a most valuable contribution to scholarship on this fascinating figure. It is to be hoped that this well-documented book will, along with Frazier's biography attract new readers to George Moore and, perhaps, be the first of many new studies on Moore, a truly European figure in a period of national stereotypes, a socially advanced thinker within the repressed patriarchy of Victorianism, a versatile artist and lover of the arts whose works are as relevant today as when they first appeared.

\section{REFERENCES}

Foster, Roy Foster. 1997. W.B. Yeats A Life: I The Apprentice Mage. Oxford: Oxford University Press.

Frazier, Adrian. 2000. George Moore, 1852-1933. New Haven and London: Yale University Press. 